\title{
Duodenal inhibition of gastric secretion by osmotic agents in normal subjects and patients with duodenal ulcer
}

\author{
A. S. WARD, R. A. WILKINS, R. COCKEL, AND C. W. O. WINDSOR \\ From the Queen Elizabeth Hospital, Edgbaston, Birmingham
}

\begin{abstract}
SUMMARY Gastric secretion in man is inhibited by the presence in the duodenum of hyperosmolar and hypoosmolar solutions. Both acid and pepsin outputs are affected. There is no change in hydrogen, sodium, or potassium ion concentration in the gastric juice. Pepsin concentration, however, is reduced by all inhibitory stimuli. Inhibition is thought to act directly upon parietal and chief cells, and a possible basis for this mechanism is discussed. The response is similar in control subjects and duodenal ulcer patients; there is in particular no evidence of impaired inhibition in the ulcer group. An anomalous feature is the relatively small inhibition of acid output after hypertonic saline in control subjects compared with the duodenal ulcer patients.
\end{abstract}

Failure of gastric inhibition is a possible cause of the hypersecretion associated with duodenal ulceration. Knowledge of the mechanisms involved has been gained mainly from animal experiments while few studies have evaluated their significance in normal subjects or ulcer patients.

Duodenal inhibition of gastric secretion was first demonstrated by Sokolov (1904), who observed that gastric juice placed in the duodenum of dogs reduced the acid response to a meat test meal. Inhibition by duodenal acidification has been confirmed both in the dog (Day and Webster, 1935; Code and Watkinson, 1955; Jones and Harkins, 1959) and in man (Barsony and Egan, 1925; Griffiths, 1936; Johnston and Duthie, 1964, 1965, and 1966). The presence of fat in the duodenum is also well documented as a cause of gastric inhibition in animals (Khigine, 1894; Lim, Ivy, and McCarthy, 1925; Menguy, 1962; Halvorsen, Middleton, Bibler, Harkins, and Nyhus, 1966) and to a lesser extent in man (Ewald and Boas, 1886; Roberts, 1931; Windsor, Cockel, and Lee, 1969).

Knowledge of the effect on the gastric secretory response of varying duodenal osmolarity is less complete. Leconte in 1900, using Pavlov-pouch dogs, was the first to demonstrate inhibition of gastric secretion by instilling hypertonic glucose into the duodenum. Others, using similar techniques, in dogs observed a decreased acid response to milk test meals (Clemm, 1901; Matsuyama, 1932), to meat (Sircus,
1958), to sham feeding (Day and Komarov, 1939), to histamine (Sircus, 1958), and to gastrin (Konturek and Grossman, 1965). In man a reduced secretory response has been shown after glucose was added to a test meal (Aldor, 1900), and after direct instillation of hypertonic glucose into the duodenum (Kauders and Porges, 1922; Gutzeit, 1930; Matsuyama, 1932; Shay, Gershon-Cohen, and Fels, 1939 and 1942b). Inhibition by carbohydrates other than glucose has been described in dogs by Sircus (1958), while in man Hunt, Macdonald, and Spurrell (1951) and Hunt (1954 and 1956) have shown that sucrose in concentrations of $10 \%$ and $20 \%$ inhibits both gastric secretion and emptying.

Few studies of the inhibition of gastric secretion by other osmotically active agents have been undertaken, though Sircus (1958) reported inhibition by hypertonic saline in dogs and Shay (1944) a similar response in man.

In this study the effect on gastric secretion of saline and glucose of varying osmolarity has been evaluated. Pentagastrin was used as the secretory stimulus and the secretory volume and concentration of acid, pepsin, and electrolytes were measured. Both normal subjects and duodenal ulcer patients were studied. The results show that hyperosmolar and hypoosmolar solutions instilled into the duodenum of man inhibit gastric secretion. There is no evidence that these mechanisms are deficient in duodenal ulcer disease although certain anomalies are described. 


\section{MATERIALS AND METHODS}

Seventeen control subjects aged 20 to 71 and 14 patients with duodenal ulcer aged 33 to 61 years were investigated. The controls were selected from medical students, hospital staff, and volunteer patients recovering from minor operations; all were free of abdominal symptoms. The ulcer patients had definite radiological evidence of chronic duodenal ulceration and were awaiting admission to hospital for surgery.

The technique used to assess the inhibitory capacity of the duodenum was that described by Windsor et al (1969). After an overnight fast a polyvinyl tube, $2 \mathrm{~mm}$ outside diameter, was introduced via the nose into the stomach and subsequently manoeuvred into the fourth part of the duodenum under fluoroscopic control. A double lumen collecting tube was then passed to lie in the gastric antrum. Sampling was by continuous suction and 10minute collections were made throughout. The basal secretory rate was measured for approximately 40 minutes and then a secretory stimulus applied using a continuous intravenous infusion of pentagastrin at a rate of $6 \mu \mathrm{g} / \mathrm{kg} / \mathrm{hr}$.

After a plateau response $i e$, three successive collections of similar volume, had been obtained (usually the third, fourth, and fifth 10 -minute collections) $40 \mathrm{ml}$ of a test solution at $37^{\circ} \mathrm{C}$ was infused into the distal duodenum over a four-minute period. Gastric collection was continued for at least a further $\mathbf{4 0}$ minutes.

The solutions used were: (1) $0.09 \%$ saline (osmolarity $30 \mathrm{~m} \mathrm{osm} / \mathrm{l}$ ); (2) $3 \%$ saline (osmolarity about 1,000 $\mathrm{m}$ osm $/ \mathrm{l}$ ); and (3) $18.5 \%$ glucose (osmolarity about $1,000 \mathrm{~m} \mathrm{osm} / \mathrm{l}$ ). The choice of these solutions was somewhat arbitrary though each was felt to constitute an adequate osmotic stimulus. The hypotonic saline (strength $0.09 \%$ ) was isomolar with Prosparol used in previous studies, and the hypertonic saline (strength $3 \%$ ) was available already made up; a glucose solution of similar osmolarity was prepared for comparison. All solutions contained $1 \%$ polyethylene glycol (PEG) to detect possible reflux from duodenum to stomach. The control subjects and ulcer patients were allocated randomly in approximately equal numbers into one of three groups. The first received hypotonic saline, the second hypertonic saline, and the third group hypertonic glucose.

In the case of the hypertonic glucose solution, samples of blood were taken for glucose estimation on three occasions during the half hour following duodenal instillation.

Control studies were carried out on five normal subjects. In three a pentagastrin infusion alone was continued for three hours to detect possible diminution of the gastric secretory response with time. None was noted. In two subjects $40 \mathrm{ml}$ physiological $(0.9 \%)$ saline was instilled into the duodenum, again without effect on the plateau response.

ESTIMATIONS ON GASTRIC ASPIRATE Five estimations were made: (1) volume of sample in $\mathrm{ml}$ per 10-minute collection period; (2) $p \mathrm{H}$ and hydrogen ion concentration by titration to $p \mathrm{H} 7$ with $0 \cdot 1 \mathrm{~N} \mathrm{NaOH}{ }^{1}$; (3) pepsin by the method of Anson (1938) and expressed as milligrams of Armour cystalline porcine pepsin; (4) sodium, potassium, ${ }^{1}$ Radiometer Equipment, Copenhagen and chloride on the AutoAnalyzer ${ }^{2}$; and (5) polyethylene glycol by a turbidimetric method (Malawer and Powell, 1967).

GASTRODUODENAL REFLUX One of the difficulties encountered in an experimental procedure such as this is reflux of duodenal contents into the stomach, particularly after instillation of the test solution. Reflux may not only render gastric acidity measurements incorrect by both neutralization and dilution, but also diminish the stimulus to the duodenal inhibitory mechanisms.

The problem was approached in two ways:

1 Polyethylene glycol was used to 'label' the duodenal instillate so that reflux could be measured. At the outset it was decided that any test in which reflux of $10 \%$ or more occurred should be discarded; however, figures of this order were not encountered. Absence of significant reflux may be attributed to instillation of reagents into the distal rather than the proximal duodenum and to the relatively slow infusion rate.

2 Estimation of gastric juice electrolytes served as a second check on reflux in the case of the hypertonic saline solutions. Despite the high concentration of sodium and chloride ions in the duodenum following such infusions, in none of eight cases tested was a significant increase in concentration of sodium or chloride ions detected in the gastric juice (Fig. 7).

It is therefore felt that changes in gastric secretion reflect a specific response induced solely by exposure of the duodenum to inhibitory stimuli.

\section{RESULTS}

ACID OUTPUT The results have been presented in three ways:

(1) Histograms show the mean acid output for each group of control subjects and ulcer patients during the test (Figs. 1, 3, and 5).

(2) The individual responses have also been represented graphically (Figs. 2, 4, and 6). The mean of the last three collections before duodenal infusion ('mean plateau output') has been compared with the lowest output after instillation ('peak inhibition output') in each case.

(3) The numerical data are given in Tables I, II, and III. The difference between the median value of the three plateau collections and the output at peak inhibition has been determined for each control subject and ulcer patient and the mean of the differences used to assess statistical significance in each group.

Hypotonic saline (group 1) Figure 1 shows the change in acid output after hypotonic saline. Inhibition occurred in both control subjects and ulcer patients; there was little difference between the two groups. The response was rapid, within five minutes of beginning the infusion, and persisted for approximately 20 minutes.

${ }^{2}$ Technicon 


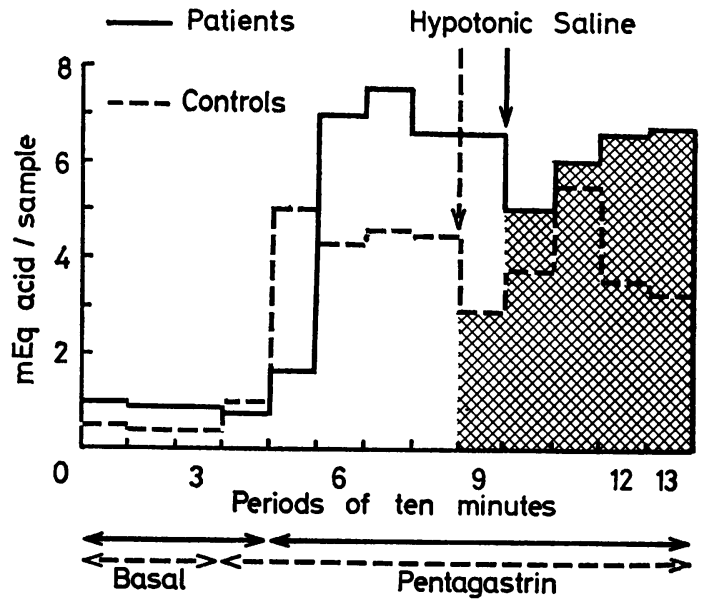

FIG. 1. The effect of hypotonic saline $(30 \mathrm{~m}$ osm $/ \mathrm{l})$ on mean acid output in control subjects and duodenal ulcer patients. Shaded columns indicate post-instillation sampling. The stimulus was pentagastrin infused at the rate of $6 \mu \mathrm{g} / \mathrm{kg} / \mathrm{hr}$. The same connotation is used in Figures 3 and 5 .

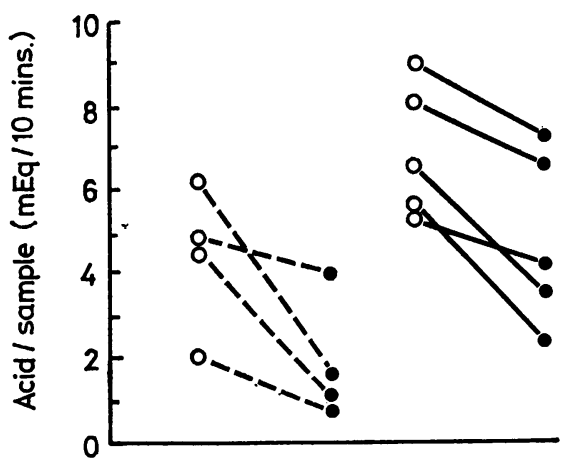

FIG. 2. The effect of hypotonic saline $(30 \mathrm{mosm} . / \mathrm{l})$ on acid output in individual control subjects (- . -) and duodenal ulcer patients $(-)$. $\bigcirc$ denotes acid output during the plateau and - the output during peak inhibition. The same connotation is used in Figures 4 and 6.
Figure 2 shows the individual changes in acid output. The numbers studied are small and inhibition reaches statistical significance only in the ulcer group $(\mathrm{P}<0.01$, Table I).

Hypertonic saline (group 2) Figure 3 shows the mean acid output before and after instillation of hypertonic saline. A reduction in output was observed in the ulcer group but there was little change in control subjects. The response was immediate and lasted for 30 minutes.

The individual results are represented in Figure 4. Inhibition is significant in the ulcer patients $(P<0.01)$ and the response in this group is greater than in control subjects $(\mathrm{P}<0.05$, Table II).

Hypertonic glucose (group 3) A reduction in acid output was noted in both control and ulcer groups after hypertonic glucose (Fig. 5). The response was again rapid and lasted for $\mathbf{3 0}$ minutes.

Individual changes are shown in Figure 6. Inhibition is significant in control subjects $(P<0.001)$ and ulcer patients $(\mathrm{P}<0.05)$. The level of significance in the ulcer group is reduced by the inclusion of one patient with an unusually high plateau output (Table III).

ACID CONCENTRATION The hydrogen ion concentration remained constant in all groups after duodenal infusion. Inhibition of acid output was therefore due solely to reduction in volume of the gastric juice. A typical response is shown in Figure 7.

ELECTROLYTE SECRETION The concentration of sodium, chloride, and potassium remained the same before and after instillation in all the experiments (Fig. 7). One feature of note was a mirror-image relationship between sodium and hydrogen ion concentration, the former falling and the latter rising under the influence of pentagastrin, until a plateau was attained. A similar observation has

TABLE I

EFFECT OF INTRADUODENAL HYPOTONIC SALINE ON ACID OUTPUT IN CONTROL SUBJECTS AND DUODENAL ULCER PATIENTS

\begin{tabular}{|c|c|c|c|c|c|c|}
\hline Group & $\begin{array}{l}\text { Acid Output } \\
\text { during } \\
\text { Plateau } \\
\text { (m-equiv/10 min) }\end{array}$ & $\begin{array}{l}\text { Acid Output } \\
\text { during } \\
\text { Inhibition } \\
\text { (m-equiv/10 min) }\end{array}$ & $\begin{array}{l}\text { Inhibition } \\
\text { (m-equiv/10 min) }\end{array}$ & $\begin{array}{l}\text { Mean }^{1} \\
(m-e q u i v / 10 \text { min })\end{array}$ & SE of Mean & Significance \\
\hline $\begin{array}{l}\text { Control } \\
\text { Subjects }\end{array}$ & $\begin{array}{ll}1 & 5 \cdot 02 \\
2 & 2 \cdot 09 \\
3 & 4 \cdot 79 \\
4 & 6 \cdot 34\end{array}$ & $\begin{array}{l}1 \cdot 24 \\
0 \cdot 89 \\
4 \cdot 18 \\
1 \cdot 80\end{array}$ & $\begin{array}{l}3 \cdot 78 \\
1 \cdot 20 \\
0 \cdot 61 \\
4 \cdot 54\end{array}$ & $2 \cdot 53$ & $1 \cdot 67$ & $P>0.05$ \\
\hline $\begin{array}{l}\text { Duodenal } \\
\text { ulcer } \\
\text { patients }\end{array}$ & $\begin{array}{ll}1 & 6.66 \\
2 & 5.49 \\
3 & 5.66 \\
4 & 7 \cdot 88 \\
5 & 9.31\end{array}$ & $\begin{array}{l}3 \cdot 58 \\
4 \cdot 26 \\
2 \cdot 46 \\
6 \cdot 55 \\
7 \cdot 31\end{array}$ & $\begin{array}{l}3 \cdot 08 \\
1 \cdot 23 \\
3 \cdot 20 \\
1 \cdot 33 \\
2 \cdot 00\end{array}$ & $2 \cdot 17$ & 0.83 & $P<0.01$ \\
\hline
\end{tabular}

${ }^{1}$ There is no significant difference between the mean inhibition for control subiects and the mean for duodenal ulcer patients. 


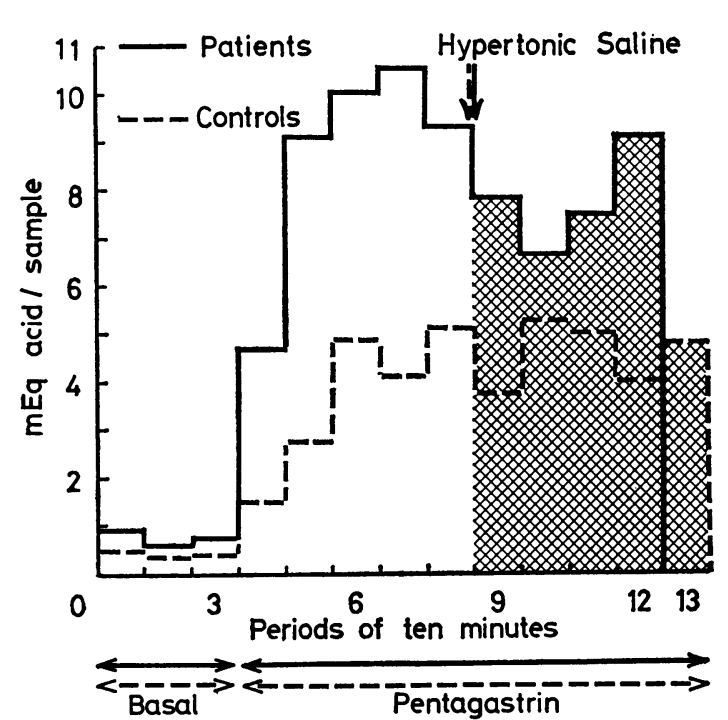

FIG. 3. The effect of hypertonic saline (about 1,000 $m$ osm/l) on mean acid output in control subjects and duodenal ulcer patients.

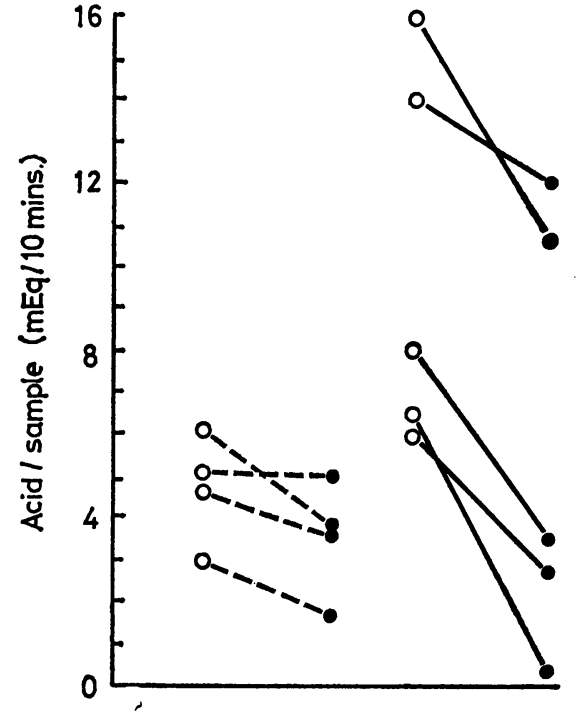

FIG. 4. The effect of hypertonic saline (about 1,000 $m$ osm/l) on acid output in individual control subjects $(--)$ and duodenal ulcer patients $(-)$.

TABLE II

EFFECT OF INTRADUODENAL HYPERTONIC SALINE ON ACID OUTPUT IN CONTROL SUBJECTS AND DUODENAL ULCER PATIENTS

\begin{tabular}{|c|c|c|c|c|c|c|c|}
\hline \multirow[b]{2}{*}{ Group } & & \multirow[b]{2}{*}{$\begin{array}{l}\text { Acid Output } \\
\text { during } \\
\text { Plateau } \\
\text { (m-equiv/10 min) }\end{array}$} & & \multirow[b]{2}{*}{ Significance } \\
\hline & & & $\begin{array}{l}\text { Acid Output } \\
\text { during } \\
\text { Inhibition } \\
\text { (m-equiv/10 min) }\end{array}$ & $\begin{array}{l}\text { Inhibition } \\
\text { (m-equiv/10 min) }\end{array}$ & $\begin{array}{l}\text { Mean } \\
\text { Inhibition } \\
\text { (m-equiv/10 min }\end{array}$ & $S E$ of Mean & \\
\hline $\begin{array}{l}\text { Control } \\
\text { subjects }\end{array}$ & $\left.\begin{array}{l}1 \\
2 \\
3 \\
4\end{array}\right\}$ & $\begin{array}{l}4 \cdot 69 \\
3 \cdot 03 \\
6 \cdot 92 \\
4 \cdot 56\end{array}$ & $\begin{array}{l}3 \cdot 77 \\
1 \cdot 65 \\
3 \cdot 79 \\
4 \cdot 22\end{array}$ & $\begin{array}{l}0.92 \\
1 \cdot 38 \\
3 \cdot 13 \\
0 \cdot 34\end{array}$ & 1.44 & $1 \cdot 05$ & $P>0.05^{1}$ \\
\hline $\begin{array}{l}\text { Duodenal } \\
\text { ulcer } \\
\text { patients }\end{array}$ & $\left.\begin{array}{l}1 \\
2 \\
3 \\
4 \\
5\end{array}\right\}$ & $\begin{array}{r}6.41 \\
16.39 \\
6.32 \\
6.05 \\
13.90\end{array}$ & $\begin{array}{r}0.32 \\
10 \cdot 76 \\
3 \cdot 29 \\
2.66 \\
12.05\end{array}$ & $\begin{array}{l}6.09 \\
5.63 \\
3.03 \\
3.39 \\
1.85\end{array}$ & $4 \cdot 00$ & $1 \cdot 61$ & $<0.01$ \\
\hline
\end{tabular}

Mean inhibition is significantly greater in duodenal ulcer patients than in control subjects $(P<0 \cdot 05)$.

TABLE III

EFFECT OF INTRADUODENAL HYPERTONIC GLUCOSE ON ACID OUTPUT IN CONTROL SUBJECTS AND DUODENAL ULCER PATIENTS ${ }^{1}$

\begin{tabular}{|c|c|c|c|c|c|c|c|}
\hline Group & & $\begin{array}{l}\text { Acid Output } \\
\text { during } \\
\text { Plateau } \\
(\text { m-equiv } / 10 \text { min })\end{array}$ & $\begin{array}{l}\text { Acid Output } \\
\text { during } \\
\text { Inhibition } \\
(\text { m-equiv/10 min) }\end{array}$ & $\begin{array}{l}\text { Inhibition } \\
\text { (m-equiv/10 min) }\end{array}$ & $\begin{array}{l}\text { Mean } \\
\text { Inhibition } \\
\text { (m-equiv/10 min) }\end{array}$ & $S E$ of Mean & Significance \\
\hline $\begin{array}{l}\text { Control } \\
\text { subjects }\end{array}$ & $\left.\begin{array}{l}1 \\
2 \\
3 \\
4\end{array}\right\}$ & $\begin{array}{l}4 \cdot 18 \\
4 \cdot 87 \\
4 \cdot 90 \\
6 \cdot 11\end{array}$ & $\begin{array}{l}0.44 \\
0.69 \\
0.46 \\
2 \cdot 36\end{array}$ & $\begin{array}{l}3 \cdot 74 \\
4 \cdot 18 \\
4 \cdot 44 \\
3 \cdot 75\end{array}$ & $4 \cdot 03$ & $0 \cdot 26$ & $P<0.001$ \\
\hline
\end{tabular}

\footnotetext{
'There is no significant difference between the mean inhibition for control subjects and the mean for duodenal ulcer patients.
} 


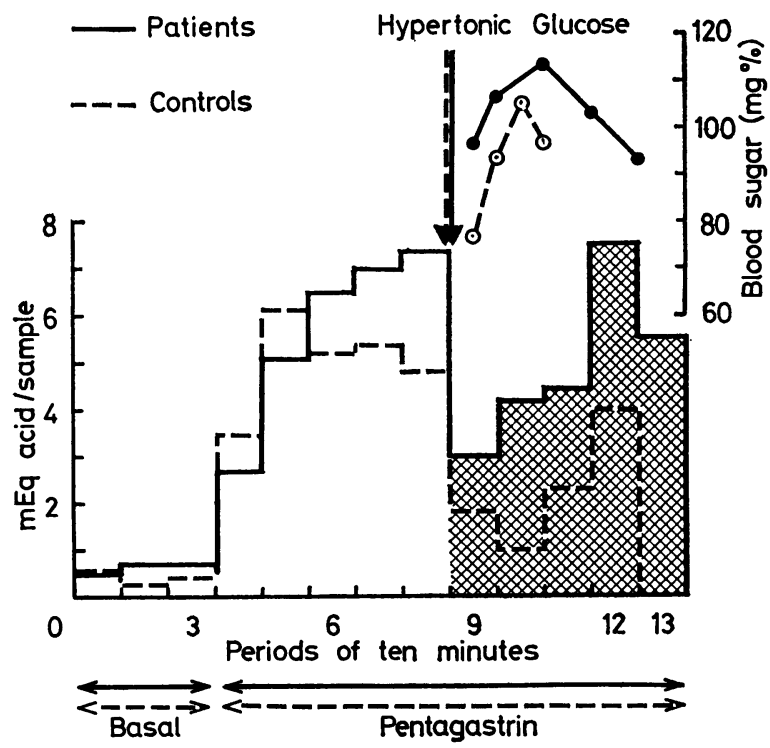

FIG. 5. The effect of hypertonic glucose (about 1,000 $m$ osm/l) on mean acid output in control subjects and duodenal ulcer patients. Blood sugar levels are indicated.

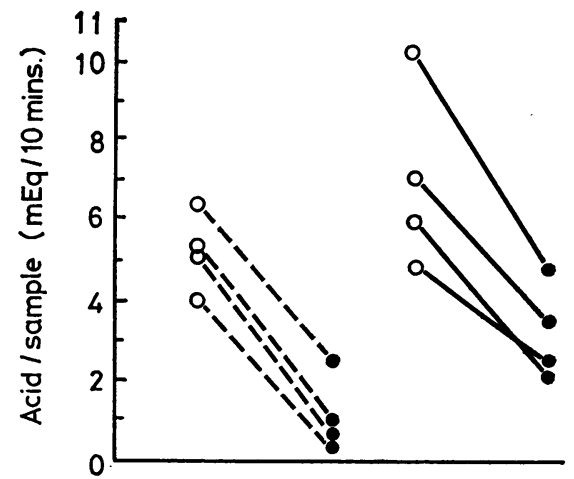

FIG. 6. The effect of hypertonic glucose (about 1,000 $m$ osm/l) on acid output in individual control subjects $(--)$ and duodenal ulcer patients (-). been made concerning the response to histamine (Nordgren, 1963).

PEPSIN OUTPUT Pepsin output was reduced in all groups after duodenal infusion. The response was similar in control subjects and ulcer patients and a typical sequence of events is shown in Figure 8.

The individual results are set out in Tables IV, V, and VI. Significance has been evaluated in the same way as for acid output by comparing the median value of the three plateau collections with the lowest output after instillation in each control subject and ulcer patient.

Inhibition is significant in all groups with the exception of the control subjects after hypotonic saline. It is interesting that pepsin output was reduced in both control and ulcer groups after hypertonic saline, whereas acid output was reduced only in the ulcer patients (compare Tables II and V).

There was no significant difference between the mean inhibition for control subjects and the mean for duodenal ulcer patients in any of the groups.

PEPSIN CONCENTRATION The pepsin concentration of the gastric juice was reduced by all inhibitory stimuli in control subjects and ulcer patients alike. This is in contrast to acid concentration which remained constant throughout. A typical response is shown in Figure 7.

Post-inhibitory rebound In several instances in both control and ulcer groups a 'rebound' increase in secretion was observed after inhibition. Volume, concentration, and total output of acid and pepsin all increased to levels above those seen in the preinstillation period. These changes persisted for 20 minutes or more in most cases.

Post-inhibitory rebound has been previously noted in dogs (Virschoubski, 1900; Orbeli, 1906; Shay et al, 1939; Sircus, 1958) and in man following the administration of fat (Roberts, 1931; Windsor and Cockel, unpublished observations). One explana-

TABLE IV

EFFECT OF INTRADUODENAL HYPOTONIC SALINE ON PEPSIN OUTPUT IN CONTROL SUBJECTS AND

\begin{tabular}{|c|c|c|c|c|c|c|}
\hline \multirow[b]{2}{*}{ Group } & \multicolumn{5}{|c|}{ DUODENAL ULCER PATIENTS } & \multirow[b]{2}{*}{ Significance } \\
\hline & $\begin{array}{l}\text { Pepsin Output } \\
\text { during } \\
\text { Plateau } \\
(\text { mg/10 min })\end{array}$ & $\begin{array}{l}\text { Pepsin Output } \\
\text { during } \\
\text { Inhibition } \\
\text { (mg/10 min) }\end{array}$ & $\begin{array}{l}\text { Inhibition } \\
(\mathrm{mg} / 10 \mathrm{~min})\end{array}$ & $\begin{array}{l}\text { Mean }^{1} \\
\text { Inhibition } \\
(\text { mg/10 min) }\end{array}$ & $S E$ of Mean & \\
\hline $\begin{array}{l}\text { Control } \\
\text { subjects }\end{array}$ & $\begin{array}{rr}1 & 6 \cdot 72 \\
2 & 16 \cdot 38 \\
3 & 13 \cdot 16\end{array}$ & $\begin{array}{r}2 \cdot 12 \\
15 \cdot 42 \\
2 \cdot 85\end{array}$ & $\begin{array}{r}4 \cdot 60 \\
0 \cdot 96 \\
10 \cdot 31\end{array}$ & $5 \cdot 29$ & $3 \cdot 84$ & $P>0.05$ \\
\hline $\begin{array}{l}\text { Duodenal } \\
\text { ulcer } \\
\text { patients }\end{array}$ & $\begin{array}{rr}1 & 14 \cdot 22 \\
2 & 9.97 \\
3 & 11 \cdot 26 \\
4 & 11 \cdot 56\end{array}$ & $\begin{array}{r}10 \cdot 21 \\
5 \cdot 28 \\
7 \cdot 34 \\
9 \cdot 28\end{array}$ & $\begin{array}{l}4 \cdot 01 \\
4 \cdot 69 \\
3.92 \\
2 \cdot 28\end{array}$ & $3 \cdot 72$ & $0 \cdot 89$ & $P<0.01$ \\
\hline
\end{tabular}

${ }^{1}$ There is no significant difference between the mean inhibition for control subjects and the mean for duodenal ulcer patients. 


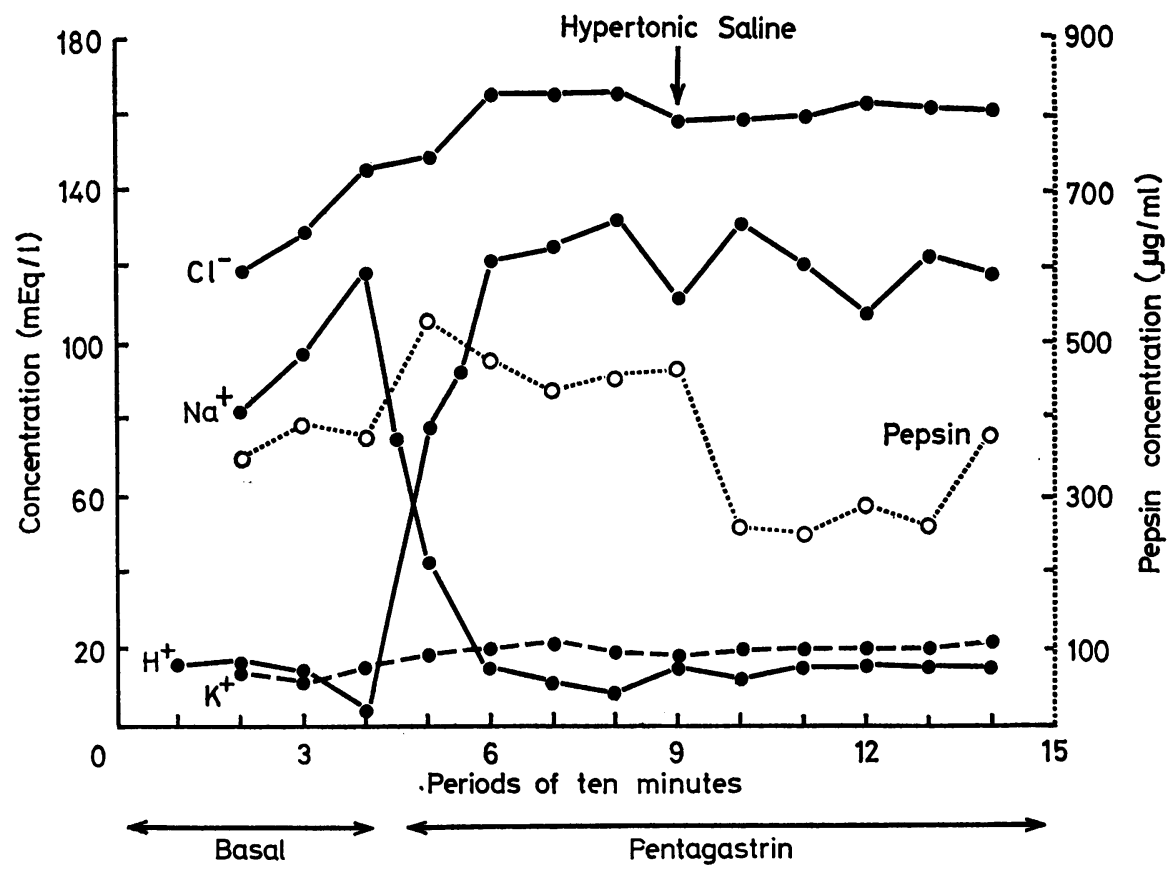

FIG. 7. The effect of hypertonic saline (about 1,000 mosm/l) on the acid, pepsin, and electrolyte concentration of gastric juice in a duodenal ulcer patient. tion is that the increase is due to secretion stored up during the inhibitory period being released (Shay et al, 1939).

\section{DISCUSSION}

This study confirms that there is a mechanism inhibiting gastric acid and pepsin secretion in man in response to duodenal instillation of hyperosmolar and hypo-osmolar solutions. Inhibition appears to vary with the solute employed, being greater after glucose than after saline of similar osmolarity. The explanation for this difference is not apparent, although variable rates and energies of absorption may be involved. Speeds of onset and recovery, however, were similar in all groups, suggesting that inhibition occurs through a common pathway stimulated by change in intraduodenal osmolarity. This accords with the observations of Sircus (1958), who in addition, defined for dogs a critical range of osmolarity (50-275 m osm/l) outside of which inhibition occurs.

The inhibitory pathway is unknown, though the rapidity with which effects are achieved favours a neural rather than a humoral mechanism. As has previously been shown for fat, the secretory response to a pentagastrin infusion is reduced, suggesting that the inhibitory effect is a direct one upon the

TABLE V

EFFECT OF INTRADUODENAL HYPERTONIC SALINE ON PEPSIN OUTPUT IN CONTROL SUBJECTS AND DUODENAL ULCER PATIENTS

\begin{tabular}{|c|c|c|c|c|c|c|c|}
\hline Group & & $\begin{array}{l}\text { Pepsin Output } \\
\text { during } \\
\text { Plateau } \\
(\mathrm{mg} / 10 \mathrm{~min})\end{array}$ & $\begin{array}{l}\text { Pepsin Output } \\
\text { during } \\
\text { Inhibition } \\
\text { (mg/10 min) }\end{array}$ & $\begin{array}{l}\text { Inhibition } \\
\text { (mg/10 min) }\end{array}$ & $\begin{array}{l}\text { Mean } \\
\text { Inhibition } \\
(\mathrm{mg} / 10 \mathrm{~min})\end{array}$ & $S E$ of Mean & Significance \\
\hline $\begin{array}{l}\text { Control } \\
\text { subjects }\end{array}$ & $\left.\begin{array}{l}1 \\
2 \\
3\end{array}\right\}$ & $\begin{array}{r}9 \cdot 94 \\
12 \cdot 60 \\
14 \cdot 96\end{array}$ & $\begin{array}{l}2 \cdot 58 \\
7 \cdot 25 \\
9 \cdot 07\end{array}$ & $\begin{array}{l}7 \cdot 36 \\
5 \cdot 35 \\
5 \cdot 89\end{array}$ & $6 \cdot 20$ & 0.85 & $P<0.01$ \\
\hline $\begin{array}{l}\text { Duodenal } \\
\text { ulcer } \\
\text { patients }\end{array}$ & $\left.\begin{array}{l}1 \\
2 \\
3 \\
4 \\
5\end{array}\right\}$ & $\begin{array}{l}17 \cdot 30 \\
48 \cdot 57 \\
12 \cdot 73 \\
15 \cdot 91 \\
25 \cdot 92\end{array}$ & $\begin{array}{r}0 \cdot 97 \\
25 \cdot 84 \\
5 \cdot 70 \\
7 \cdot 47 \\
20 \cdot 39\end{array}$ & $\begin{array}{r}16 \cdot 33 \\
22 \cdot 73 \\
7 \cdot 03 \\
8 \cdot 44 \\
5 \cdot 53\end{array}$ & $12 \cdot 01$ & $6 \cdot 52$ & $P<0.05$ \\
\hline
\end{tabular}

${ }^{1}$ There is no significant difference between the mean inhibition for control subjects and the mean for duodenal ulcer 

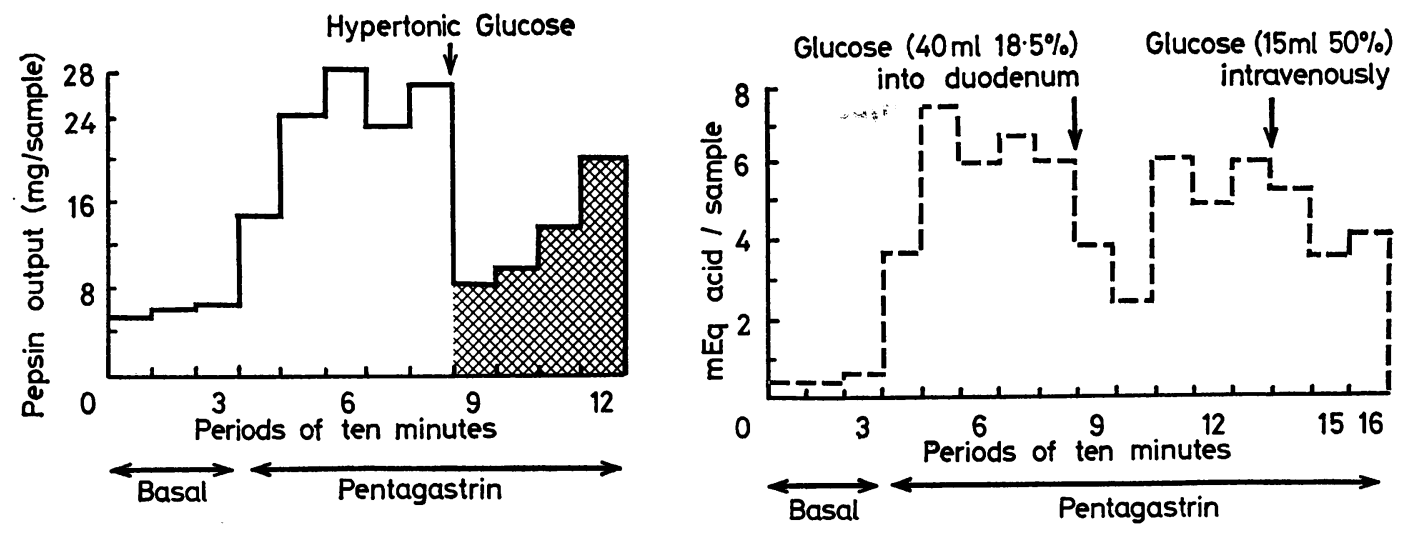

FIG. 8.

FIG. 9.

FIG. 8. The effect of hypertonic glucose (about $1,000 \mathrm{~m}$ osm/l) on mean pepsin output in duodenal ulcer patients. The output is expressed as mg pepsin per 10-minute sample.

FIG. 9. Comparison of the effect on acid output of intraduodenal and intravenous glucose in a control subject.

parietal and chief cells. An alternative hypothesis is that a change in the acid secretion rate might be directly dependent upon alteration in gastric mucosal blood flow, as observed in dogs (Thompson and Vane, 1953). Osmotically active solutions introduced into the duodenum may cause redistribution of gastrointestinal blood flow due to movement of water or solute between mesenteric vessels and intestinal lumen. Gastric mucosal flow may be decreased at the expense of increased intestinal flow. This hypothesis does not, however, explain the similar response to both increased and decreased duodenal osmolarity.

The action of glucose requires further consideration. Early reports suggested that inhibition of gastric secretion by duodenal instillation of glucose was an effect of hyperglycaemia (Okada, Kuramochi, Tsukahara, and Oionoue, 1929). However, Roholm (1930) found no change in gastric secretion during adrenaline-induced hyperglycaemia and Kalk and
Meyer (1932) no effect with intravenous glucose. On the other hand, both Matsuyama (1933) and Shay et al (1942b) observed that intravenous glucose alone produced slight inhibition. Day and Komarov (1939) demonstrated that the gastric acid output after duodenal instillation of glucose decreased before a rise in blood sugar, and Shay et al (1942b) showed that prevention of hyperglycaemia, by synchronous insulin injections, did not abolish the effect of duodenal glucose on gastric acidity, although it did reduce its magnitude. The latter authors concluded that glucose exerted an inhibitory effect mainly by a local osmoreceptor mechanism with a small additional component from the attendant hyperglycaemia.

Our findings support the views of Shay et al (1942b); in seven out of eight cases inhibition occurred before a rise in blood sugar (Fig. 5). In one control subject the effects of duodenal and intravenous glucose were investigated in sequence (Fig. 9). Although comparable blood sugar levels were

TABLE VI

EFFECT OF INTRADUODENAL HYPERTONIC GLUCOSE ON PEPSIN OUTPUT IN CONTROL SUBJECTS AND DUODENAL ULCER PATIENTS

\begin{tabular}{|c|c|c|c|c|c|c|c|}
\hline Group & & $\begin{array}{l}\text { Pepsin Output } \\
\text { during } \\
\text { Plateau } \\
(\text { mg } / 10 \text { min })\end{array}$ & $\begin{array}{l}\text { Pepsin Output } \\
\text { during } \\
\text { Inhibition } \\
(\mathrm{mg} / 10 \mathrm{~min})\end{array}$ & $\begin{array}{l}\text { Inhibition } \\
(\mathrm{mg} / 10 \mathrm{~min})\end{array}$ & $\begin{array}{l}\text { Mean }{ }^{1} \\
\text { Inhibition } \\
(\mathrm{mg} / 10 \mathrm{~min})\end{array}$ & $S E$ of Mean & Significance \\
\hline $\begin{array}{l}\text { Control } \\
\text { subjects }\end{array}$ & $\left.\begin{array}{l}1 \\
2 \\
3 \\
4\end{array}\right\}$ & $\begin{array}{l}12 \cdot 99 \\
10 \cdot 49 \\
16 \cdot 92 \\
13 \cdot 61\end{array}$ & $\begin{array}{l}1 \cdot 47 \\
1 \cdot 23 \\
1 \cdot 09 \\
5 \cdot 58\end{array}$ & $\begin{array}{r}11 \cdot 52 \\
9 \cdot 26 \\
15 \cdot 83 \\
8 \cdot 03\end{array}$ & $11 \cdot 16$ & $2 \cdot 98$ & $P<0.01$ \\
\hline
\end{tabular}

'There is no significant difference between the mean inhibition for control subjects and the mean for duodenal ulcer patients. 
achieved the response was greater after intraduodenal than after intravenous administration. Part of the latter effect may, in addition, have been due to the unpleasantness of venepuncture rather than to hyperglycaemia.

Reduction in acid output was due to a decreased volume of gastric juice as there was no change in hydrogen, sodium, or potassium ion concentration. By contrast, pepsin concentration was reduced in all groups and this contributed appreciably to the overall reduction in pepsin output. The significance of this different degree of inhibition of the products of the gastric mucosa is unknown, although it may be analogous to the variable pepsin: $\mathrm{HCl}$ ratio $\left(\mathrm{K}_{25}\right)$ observed by Bonfils, Lewin, Vatier, Dubrasquet, and Bader (1968) in response to gastrin, histamine, or vagal stimulation. A similar ratio may exist with respect to humoral and neural inhibitory agents; further information is needed on this subject.

In addition to demonstrating osmotically induced inhibition of gastric secretion in man we have investigated the response in duodenal ulcer patients. Previous workers have failed to show an unequivocal abnormality of inhibition in response to intraduodenal acid (Hunt, 1957; Johnston and Duthie, 1964 and 1965) or fat (Windsor et al, 1968), although Shay et al (1942a) have disagreed. In the present study hypotonic saline and hypertonic glucose produced a similar response in both control subjects and duodenal ulcer patients. However, one difference did emerge between the two groups: hypertonic saline definitely inhibited acid output in the duodenal ulcer group but had only a small effect in the controls. This finding was quite unexpected and remains so far unexplained.

We wish to thank the Endowment Research Committee of the United Birmingham Hospitals for financial support. In addition we acknowledge the constant help of Shiela Nutter, technician in the gastroenterology laboratory.

\section{REFERENCES}

Aldor, L. von, (1900). Ueber die künstliche Beeinflussung der Magensekretion. Ztschr. f. klin. Med., 40, 248-265.

Anson, M. L., (1938). The estimation of pepsin, trypsin, papain and cathepsin with haemoglobin. J. Gen. Physiol., 22, 79-89.

Barsony, T., and Egan, E., (1925). Ueber den duodenalen Pylorusreflex nach Röntgenuntersuchungen am Menschen mit der Gastroduodenal-Doppelsonde. Münch. med. Wchnschr., 72, 12421244.

Bonfils, S., Lewin, M., Vatier, J., Dubrasquet, M., and Bader, J. P., (1968). Correlation between acid and peptic secretion in man (Coefficient K25). In The Physiology of Gastric Secretion, edited by L. S. Semb, and J. Myren, pp. 164-173.

Clemm, W. N. (1901). Ueber die Beeinflussung der Magensaftabscheidung durch Zucker. Therap. Monatshefte, 15, 403-411.

Code, C. F., and Watkinson, G. (1955). Importance of vagal innervation in the regulatory effect of acid in the duodenum on gastric secretion of acid. J. physiol. (Lond.), 130, 233-252.
Day, J. J., and Webster, D. R. (1935). The autoregulation of the gastric secretion. Amer. J. dig. Dis. 2, 527-531.

Day, J. J., and Komarov, S. A. (1939). Glucose and gastric secretion. Amer. J. dig. Dis., 6, 169-175.

Ewald, C. A., and Boas, J. (1886). Beiträge zur Physiologie und Pathologie der Verdauung II. Virchows Arch, path. Anat., 104, 271-305.

Griffiths, W. J., (1936). The duodenum and the automatic contol of gastric acidity. J. Physiol., Lond., 87, 34-40.

Gutzeit, E. (1930). Uber die Beeinflussung der Magenreiz und Nüchternsekretion durch Dünndarmverweilsonden sowiedurch duodenale und jejunale Nahrungszufuhr. Z. ges. exp. Med., 73, 48-56.

Halvorsen, H. C., Middleton, M. D., Bibler, D. D., Harkins, H. N., and Nyhus, L. M. (1966). Influence of the vagus nerve on the inhibitory effect of fat in the duodenum. Amer. J. dig. Dis., 11, 911-917.

Hunt, J. N.(1954). The inhibitory action of sucrose on gastric digestive activity in patients with peptic ulcer. Guy's Hosp. Rep., 103, 161-173.

-, (1956). Some properties of an alimentary osmoreceptor mechanism. J. Physiol., Lond., 132, 267-288.

-, (1957). The influence of hydrochloric acid on gastric secretion and emptying in patients with duodenal ulcer. Brit. med.J., 1, 681-684.

-, Macdonald, I., and Spurrell, W. R. (1951). The gastric response to pectin meals of high osmotic pressure. J. Physiol., Lond., $115,185-195$.

Johnston, D., and Duthie, H. L. (1964). Effect of acid in the duodenum on histamine-stimulated gastric secretion in man. Gut, 5, 573-580.

- - (1965). Inhibition of gastric secretion in the human stomach. Lancet, 2, 1032-1036.

- , (1966). Inhibition of histamine-stimulated gastric secretion by acid in the duodenum in man. Gut, 7, 58-68.

Jones, T. W., and Harkins, H. N. (1959). The mechanism of inhibition of gastric acid secretion by the duodenum. Gastroenterology, 37, 81-86.

Kalk, H., and Meyer, P. F. (1932). Blutzuckerspiegel und Magensekretion. Z. klin. Med., 120, 692-714.

Kauders, F., and Porges, O. (1922). Der Einfluss des Duodenalinhaltes auf die Magensekretion. Wien. klin. Wchnschr., 35, 838-839.

Khigine, P. (1894). Activité sécrétoire de l'estomac du chien. Arch. sci. biol., 3, 461-525.

Konturek, S., and Grossman, M. I. (1965). Effect of perfusion of intestinal loops with acid, fat or dextrose on gastric secretion. Gastoenterology, 49, 481-489.

Lecontè, P. (1900). Fonctions gastro-intestinales. Etude physiologique Cellule, 17, 283-321.

Lim, R. K. S., Ivy, A. C., and McCarthy, J. E. (1925). Contributions to the physiology of gastric secretion. Quart. J. exp. Physiol., $15,13-68$.

Malawer, S. J., and Powell, D. W. (1967). An improved turbidimetric analysis of polyethylene glycol utilizing an emulsifier. Gastroenterology, 53, 250-256.

Matsuyama, M. (1932). Influence of the introduction of glucose into the intestine upon the secretion of the gastric juice. Jap. J. Gastro-ent., 4, 273-279.

-, (1933). Influence of the intravenous and subcutaneous administration of glucose upon the secretion of the gastric juice. Jap. J. Gastroent., 5, 37-47.

Menguy, R. (1962). Duodenal regulation of gastric secretion. Ann. N.Y. Acad. Sci., 99, 45-53.

Nordgren, B. (1963). The rate of secretion and electrolyte content of normal gastric juice. Acta. physiol. scand. supp. 202, 1-83.

Okada, S., Kuramochi, K., Tsukahara, T., and Ooinoue, T. (1929), Pancreatic function IV. The humoroneural regulation of the gastric, pancreatic and biliary secretions. Arch. Intern. Med., 43, 446-471.

Orbeli, L. A. (1906). Comparison of the activity of the peptic glands before and after section of the pneumo-gastric nerves. Arch. Sci. biol., 12, 71-103.

Roberts, W. M. (1931). The effect of oils on gastric secretion and motility. Quart. J. Med., 24, 133-152.

Roholm, K. (1930). Clinical investigations into the effect of intravenous injection of insulin. on gastric secretion in normal individuals. Acta med. scand., 73, 472-492.

Shay, H. (1944). Pathologic physiology of gastric and duodenal ulcer. Bull. N.Y. Acad. Med., 20, 264-291. 
- Gershon-Cohen, J., and Fels, S. S. (1939). The role of the upper small intestine in the control of gastric secretion: the effect of neutral fat, fatty acid and soaps; the phase of gastric secretion influenced and the relative importance of the psychic and chemical phases. Ann. intern. Med., 13, 294-307.

,,,$---(1942 a)$. A self regulatory duodenal mechanism for gastric acid control and an explanation for the pathologic gastric physiology in uncomplicated duodenal ulcer. Amer. $J$. dig. Dis., 9, 124-128.

,$- \frac{\text { alg. }}{-}$, , and Siplet, H. (1942b). Concerning the influence of glucose on the response of the human stomach to test meals. Amer. J. dig. Dis., 9, 363-367.

Sircus, W. (1958). Studies on the mechanisms in the duodenum inhibiting gastric secretion. Quart. J. exp. Physiol., 43, 114-133.
Sokolov, A. P. (1904). Analysis of the secietory work of the stomach in the dog. Thesis, F. Vaisberg and P. Gershunim, St Petersburg, quoted by Babkin, B. P. (1950). In Secretory Mechanism of the Digestive Glands, 2nd ed., p. 642.

Thompson, J. E., and Vane, J. R. (1953). Gastric secretion induced by histamine and its relationship to the rate of blood flow. J. Physiol. (Lond.), 121, 433-444.

Virschoubski, A. M. (1900). Du travail des glandes gastriques en rapport avec les différentes espèces d'aliments gras. Bolnitsch. Gaz. Botkina, 11, 1177-1183.

Windsor, C. W. O., Cockel, R., and Lee, M.J.R. (1969). Inhibition of gastric secretion in man by intestinal fat infusion. Gut, 10, $135-142$

\section{The November 1969 Issue}

\section{THE NOVEMBER 1969 ISSUE CONTAINS THE FOLLOWING PAPERS}

Solitary ulcer of the rectum M. R. MADIGAN and B. C. MORSON

A controlled trial of a protein-free liver extract in the treatment of chronic liver disease P. J. TOGHILL, R. P. KNILL-JONES, and ROGER WILLIAMS

Primary intrahepatic obliterating cholangitis: a possible variant of 'sclerosing cholangitis' P. S. BHATHAL and L. W. POWELL

Cerebral blood flow and metabolism in hepatic cirrhosis before and after portacaval shunt operation G. BIANCHI PORRO, A. T. MAIOLA, and P. DELlA PORTA

Management of hepatic coma complicating viral hepatitis R. C. PIROLA, J. M. HAM, and R. G. ELMSLIE

The use of ultrasound in the diagnosis of cystic lesions of the liver and upper abdomen and in the detection of ascites C. F. MCCARTHY, P. N. T. WELLS, F. G. M. ROSS, and A. E. A. READ

Measurement of duodenal tryptic activity and ${ }^{75} \mathrm{Se}-$ selenomethionine pancreatic scanning compared as tests of pancreatic function D. M. MCCARTHY and P. BROWN

Transmural electrical potential difference of the human colon MICHAEL G. GEALL, ROBERT J. SPENCER, and SIDNEY F. PHILLIPS
Regional enteritis leading to carcinoma of the small bowel A. P. WYATT

A comparison between the gastric and salivary concentration of iodide, pertechnetate, and bromide in man R. MCG. HARDEN, W. D. ALEXANDER, J. SHIMMINS, and D. CHISHOLM

Viscosity of gastric mucus in duodenal ulceration JOHN R. N. CURT and ROBERT PRINGLE

Spontaneous achlorhydria with atrophic gastritis in the Zollinger-Ellison syndrome H. G. DESAI and F. P. ANTIA

A study of the small intestinal mucosa using the scanning electron microscope M. N. MARSH and J. A. SWIFT

Gastroenterological Society of Australia

\section{Progress report}

The role of cyclic adenosine-3', 5'-monophosphate (AMP) in gastrointestinal secretion T. SCRATCHERD and R. M. CASE

\section{Comment}

Notes and activities

Copies are still available and may be obtained from the PUBLISHING MANAGER, BRITISH MEDICAL ASSOCIATION, TAVISTOCK SQUARE W.C.1. price 17s. 6D. 